\title{
Drug delivery systems: advanced technologies potentially applicable in personalised treatment, educational measures
}

Jorge FJ Coelho

From EPMA-World Congress 2013

Brussels, Belgium. 20-21 September 2013

This seminar intends to present a book recently published that is part of a series dedicated to recent advances on preventive, predictive and personalised medicine (PPPM). It is mainly focused on the theme of "Drug delivery systems: advanced technologies potentially applicable in personalised treatments". The critical topics involving the development and preparation of effective drug delivery systems, such as: polymers available, self-assembly, nanotechnology, pharmaceutical formulations, three dimensional structures, molecular modelling, tailor-made solutions and technological tendencies, are carefully discussed. The understanding of these areas constitutes a paramount route to establish personalised and effective solutions for specific diseases and individuals. This book was organised to constitute an important reference for didactic purposes as well as to provide the state-of-art on the area of DDS applicable in personalised treatments.

Submit your next manuscript to BioMed Central and take full advantage of:

- Convenient online submission

- Thorough peer review

- No space constraints or color figure charges

- Immediate publication on acceptance

- Inclusion in PubMed, CAS, Scopus and Google Scholar

- Research which is freely available for redistribution 